\title{
STUDI TENTANG KEMANDIRIAN LANJUT USIA DI KOTA MADIUN \\ DITINJAU DARI DUKUNGAN SOSIAL DAN OPTIMISME
}

Dahlia Novarianing Asri

\begin{abstract}
Abstrak
Penelitian ini bertujuan untuk mengetahui kemandirian lanjut usia (lansia) ditinjau dari dukungan sosial dan optimisme. Penelitian ini juga ingin mengetahui kemandirian lansia ditinjau dari jenis kelaminnya, antara laki-laki dan perempuan.

Pengumpulan data dilakukan dengan skala kemandirian, skala dukungan sosial, dan skala optimisme. Subjek dalam penelitian ini adalah 68 lansia yang ada di Kota Madiun yang terdiri dari 35 lansia laki-laki dan 33 lansia perempuan. Hasil analisis regresi pada lansia diperoleh $\mathrm{R}=0,347$, dan $\mathrm{p}=0,015$, pada taraf signifikansi $<0,05$. Hasil ini menunjukkan bahwa ada hubungan positif yang signifikan antara kemandirian lansia dengan dukungan sosial dan optimisme, dengan sumbangan efektif sebesar $12,1 \%$. Hasil ini juga menunjukkan bahwa hipotesis pertama diterima.

Hasil analisis regresi pada lansia diperoleh $\mathrm{R}=0,244$, dengan $\mathrm{p}=0,022$, pada taraf signifikansi $<0,05$. Hasil ini menunjukkan bahwa ada hubungan positif yang signifikan antara dukungan sosial dengan kemandirian lansia, dengan sumbangan efektif sebesar 9,61\%. Hasil ini juga menunjukkan bahwa hipotesis kedua diterima.

Hasil analisis regresi pada lansia diperoleh $R=0,301$, dengan $p=0,005$, pada taraf signifikansi $<0,01$. Hasil ini menunjukkan bahwa ada hubungan positif yang sangat signifikan antara optimisme dengan kemandirian lansia, dengan sumbangan efektif sebesar 5,95 \%. Hasil ini juga menunjukkan bahwa hipotesis ketiga diterima. Hasil analisis uji t-test diperoleh mean laki-laki 24,31, mean perempuan 24,06, $\mathrm{t}=0,240, \mathrm{p}=0,811$, dengan $\mathrm{p}>0,05$. Hasil analisis ini menunjukkan bahwa tidak terdapat perbedaan kemandirian dalam jenis kelamin antara lansia laki-laki dan lansia perempuan. Hasil ini juga menunjukkan bahwa hipotesis keempat ditolak.
\end{abstract}

Kata Kunci : dukungan sosial, optimisme, kemandirian dan lansia

\section{Pendahuluan}

Kajian tentang lanjut usia menjadi sangat penting terkait dengan semakin meningkatnya populasi lanjut usia di negara Indonesia. B. Darmojo (2007:32) menjelaskan bahwa berdasarkan data dari Biro Pusat Statistik (BPS) pada tahun 
2020 nanti jumlah lanjut usia di Indonesia diperkirakan akan mencapai 18.822.879 jiwa atau 11,34\% dari jumlah penduduk pada tahun 2002.

Hal yang kemudian menjadi pertanyaan adalah seberapa besar pengaruh keberadaan lansia tersebut terhadap berbagai sektor pembangunan di suatu negara atau daerah. Besarnya persentase lansia membawa beberapa konsekuensi bagi negara, keluarga maupun kehidupan lansia sendiri. Efek bagi negara yaitu besarnya prosentase lansia akan menyedot anggaran pemerintah yang besar untuk menyediakan berbagai fasilitas sosial ekonomi bagi penduduk lansia.

Implikasi secara ekonomi dengan peningkataan lansia adalah dalam rasio ketergantungan lansia (old age dependency ratio), yaitu setiap penduduk usia produktif akan menanggung semakin banyak penduduk lansia. Berubahnya struktur keluarga dari extended family ke nuclear family juga membawa dampak semakin mengecilnya jumlah rata-rata anggota dalam setiap rumah.

Masrun, dkk (1996: 86) melakukan penelitian menunjukkan hasil bahwa kemandirian meningkat sampai sekitar usia 40-50 tahun dan mulai menurun setelah usia 50 tahun. Penurunan secara tajam setelah menginjak usia 60 tahun, sehingga diambil kesimpulan bahwa lansia adalah orang yang tergantung atau kurang mandiri.

Haditono (1999: 89) melakukan penelitian kebutuhan lanjut usia. Masalah kemandirian menjadi cukup berperan bagi lansia terutama bagi lansia yang tinggal di rumah sendiri. Hal tersebut terkait dengan adanya keinginan lansia untuk masih tetap berperan dan tidak membebani orang lain (anak atau cucu) walaupun kondisi lansia yang semakin menurun dalam segala aspek kehidupannya. Haditono juga 
melakukan wawancara terhadap lansia mengenai apa yang membuat lansia bahagia, dan diperoleh hasil bahwa "mandiri" menempati porsi yang cukup besar $(10,67 \%)$ setelah "anak telah berhasil atau mandiri" (34,67\%), "keluarga harmonis" (13,33\%), dan "melakukan aktivitas sosial" (12,00\%).

Menurut Hurlock (1993: 73), kemandirian lanjut usia dipengaruhi oleh perbedaan jenis kelamin, karena di dalam kehidupan sehari-hari lingkungan sosial memberikan perlakuan yang berbeda-beda antara wanita dan pria. Sejalan dengan pendapat yang dikemukakan oleh Smart dan Smart (1998: 78) yang menjelaskan bahwa ketergantungan lebih memungkinkan terjadi pada wanita yang dimulai sejak anak-anak, sedang pada anak laki-laki lebih memiliki kesempatan untuk merubahnya sehingga laki-laki lebih dapat mandiri sesuai dengan pertumbuhannya.

Kemandirian lanjut usia juga dipengaruhi oleh faktor dukungan sosial dan optimisme. Dukungan sosial adalah sebagai tindakan yang bersifat memberi yang melibatkan emosi, pemberian informasi, bantuan instrumen, dan penilaian positif pada individu dalam menghadapi permasalahannya (House dan Kahn, 1995: 75).

Dukungan sosial (social support) didefinisikan oleh Gottlieb (2003: 63) sebagai informasi verbal atau nonverbal, saran, bantuan yang nyata atau tingkah laku yang diberikan oleh individu-individu yang akrab dengan subjek di dalam lingkungan sosialnya atau yang berupa kehadiran dan hal-hal yang dapat memberikan keuntungan emosional atau berpengaruh pada tingkah laku penerimanya. 
Sarason (2003:83) menyatakan bahwa dukungan sosial adalah keberadaan, kesediaan, kepedulian dari individu-individu yang dapat diandalkan, menghargai dan menyayanginya. Cobb (dalam Sarason, 1983) mendefinisikan dukungan sosial sebagai adanya kenyamanan, perhatian, penghargaan atau menolong individu dengan sikap menerima kondisinya. Dukungan sosial tersebut dapat diperoleh baik dari perorangan maupun dari kelompok.

Cohen dan Syme (2005: 85) menerangkan ada beberapa faktor yang mempengaruhi efektivitas dukungan sosial, antara lain : pemberi dukungan sosial; jenis dukungan; penerima dukungan; permasalahan yang dihadapi; waktu pemberian dukungan; maupun lamanya pemberian dukungan.

Pemikiran yang selalu bisa melihat sisi baik atau positif dari setiap permasalahan yang ada biasa disebut optimis atau disebut juga sebagai optimisme. Optimisme digambarkan sebagai suatu pola pikir positif yang selalu bisa melihat sisi positif dari segala hal yang menimpanya (Vaughan, $2005: 90$ ).

Lestari (2004: 55) mendefinisikan optimisme sebagai pemusatan perhatian pada hal-hal yang positif untuk mengekspresikan pikiran yang ada. Pandangan 'positive thinking' dalam optimisme mengatakan bahwa optimisme terdiri dari mengulang kata-kata yang mendukung pada diri kita sendiri, seperti "setiap hari dalam kondisi apa saja, saya selalu lebih baik dan lebih baik". Individu yang optimis mengandalkan keyakinan bahwa setiap masalah pasti ada pemecahannya. Individu yang berfikir positif tidak mudah putus asa akibat hambatan yang dihadapi (Peale, dalam Lestari; 2004: 57). Optimisme atau berpikir positif 
merupakan pola pikir positif yang digunakan seseorang dalam menghadapi masalah yang menekannya (Seligman, 2001: 95).

Clark (dalam McGinnis, 2005: 16) menyatakan bahwa tumbuhnya optimisme dipengaruhi oleh pengalaman bergaul dengan individu-individu di sekitarnya. Clark (dalam Seligman, 2001: 94) menambahkan bahwa kritik pesimis dari individuindividu yang dihormati seperti orang tua, guru, maupun pelatih akan membuat individu belajar mengkritik dirinya dengan gaya penjelasan yang pesimis pula.

Seligman (2001: 98) menjelaskan tentang aspek-aspek yang terdapat dalam optimisme, aspek-aspek tersebut berkaitan dengan cara individu menjelaskan suatu peristiwa (explanatory style) baik peristiwa yang menyenangkan ataupun peristiwa yang tidak menyenangkan. Ada tiga aspek penting yang terdapat pada individu yang optimis, yaitu: (1) kepermanenan (permanence), (2) pervasif (pervasiveness), dan (3) personalisasi (personalization)

Santrock (2007: 122) menyatakan bahwa berdasarkan perspektif perkembangan (life span perspective of development) manusia berkembang sejak masa konsepsi sampai dengan meninggal dunia, sehingga pandangan yang mengatakan bahwa lansia sudah tidak dapat berkembang merupakan pandangan yang pesimis. Pandangan ini dapat membangun citra buruk dan melemahkan semangat lansia untuk tetap bertahan hidup dan menghasilkan suatu karya yang berguna. Lansia yang memiliki pengalaman luas dan pandangan yang matang 
sering menjadi pusat penyelesaian masalah (paran para) sehingga lansia dapat tetap berkiprah dalam masyarakat.

Ada nilai luhur yang dapat diteladani dari lansia yaitu kemampuan dalam "pengelolaan rasa" sehingga bila lansia kurang mampu melakukan hal tersebut dapat memalukan. Lansia yang mampu melakukan pengelolaan rasa akan sangat berpengaruh dalam pergaulan lansia di mana lansia mampu menempatkan diri secara tepat dan hal ini tidak lepas dari dukungan sosial yang diterima lansia sehingga akan memudahkan lansia untuk tetap berkiprah dalam masyarakat. Dari uraian di atas dapat disimpulkan bahwa dukungan sosial dan optimisme cukup berperan dalam kaitannya untuk meningkatkan kemandirian lansia. Oleh sebab itu maka cukup penting untuk melakukan penelitian yang berkaitan dengan kemandirian lansia ditinjau dari dukungan sosial dan optimisme.

Berdasarkan latar belakang masalah di atas, maka masalah penelitian ini dirumuskan sebagai berikut: (1) bagaimanakah kemandirian lansia ditinjau dari dukungan sosial dan optimisme?, (2) bagaimana tingkat kemandirian lansia bila ditinjau dari jenis kelamin?

Penelitian ini bertujuan untuk mengetahui kemandirian lansia ditinjau dari dukungan sosial dan optimisme serta perbedaannya berdasarkan jenis kelamin. Penelitian ini diharapkan dapat memberikan sumbangan teoretis khususnya pada Psikologi Perkembangan tentang pemahaman terhadap kemandirian, dukungan sosial maupun optimisme khususnya pada lansia. 


\section{Metode Penelitian}

Variabel yang dipergunakan dalam penelitian terdiri dari: (1) variabel dependent/tergantung: kemandirian lansia, (2) variabel independent/bebas: dukungan sosial dan optimisme, dan (3) variabel moderator, yaitu jenis kelamin.

Subjek dalam penelitian ini adalah warga Kelurahan Mojorejo, Kecamatan Taman, Kota Madiun. Sedangkan untuk uji coba peneliti mengambil anggota PWRI Ranting 04, Kecamatan Manguharjo, Kota Madiun dan ditambah dengan warga lansia sekitar tempat tinggal subjek penelitian yang memiliki kriteria yang telah ditentukan. Sampel untuk uji coba sejumlah 40 subjek.

Pengambilan sampel dalam penelitian ini menggunakan purposive random sampling, di mana sudah ditetapkan kriteria-kriteria tertentu dalam penentuan subjek penelitian, yaitu: (1) berusia minimal 60 tahun, (2) masih mempunyai pasangan hidup, (3) secara fisik sehat (dalam arti tidak sedang sakit), dan (4) tinggal di rumah

Teknik pengumpulan data yang dilakukan dalam penelitian ini adalah dengan menggunakan skala yang disusun oleh peneliti sendiri dengan mengacu pada teori-teori yang sudah adea. Skala berisi aitem-aitem yang dikelompokkan menjadi aitem yang bersifat favorable yaitu aitem yang mendukung pernyataan dan unfavorable yaitu aitem yang tidak mendukung pernyataan.

Skala yang dipergunakan untuk pengumpulan data dalam penelitian ini dapat diuraikan sebagai berikut: (1) skala I atau disebut skala kemandirian berdasarkan pada Masrun, dkk (1996: 86) yang mencakup 5 (lima) aspek, yaitu (a) bebas; (b) inisiatif; (c) gigih; (d) percaya diri; dan (e) pengendalian diri, (2) 
skala II atau yang disebut skala dukungan sosial, disusun oleh peneliti berdasarkan teori dari House (dalam Smet, 2004: 74) yang meliputi 4 (empat) aspek, yaitu: (a) dukungan emosional; (b) dukungan penghargaan; (c) dukungan informasi, dan (d) dukungan instrumental yang berupa bantuan langsung, biasanya berupa barang atau material, (3) skala III atau merupakan skala optimisme yang disusun oleh peneliti dengan mengacu pada teori Seligman (1995) yang terdiri dari 3 (tiga) aspek yaitu (a) permanence; (b) pervasiveness; (c) personalization.

Validitas pengukuran yang digunakan dalam penelitian in adalah content validity, yang lebih banyak disandarkan pada relevansi isi pernyataan yang disusun berdasarkan kisi-kisi yang tepat (Azwar, 2008: 64). Analisis aitem dilakukan dengan mengkorelasikan skor aitem dengan skor total yang menghasilkan suatu indeks validitas aitem yang dikenal dengan sebutan indeks daya diskriminasi aitem atau indeks konsistensi aitem total. Teknik koefisien korelasi yang diacu dalam penelitian dengan menggunakan teknik koefisien alpha dari Cronbach. Peneliti menetapkan batasan kriteria 0.30 sampai 1.0.

Teknik yang digunakan dalam penentuan reliabilitas skala adalah teknik reliabilitas alpha. Pertimbangan penggunaan reliabilitas alpha karena subjek hanya dikenai satu kali perlakuan (single trial administration) sehingga tidak memungkinkan untuk menggunakan pendekatan paralel.

Data yang telah diperoleh dari subjek penelitian yaitu: kemandirian, dukungan sosial, dan optimisme untuk selanjutnya dianalisis dengan menggunakan analisis statistik. Data ini memerlukan pengolahan lebih lanjut agar 
dapat memiliki makna dan manfaat yang sesuai dengan tujuan penelitian. Sebelum dilakukan uji hipotesis, dilakukan uji prasyarat terlebih dahulu. Hipotesis 1 sampai 3 diuji dengan menggunakan metode korelasi, sehingga maka uji prasyarat yang dilakukan meliputi uji nermalitas sebaran dan uji linearitas sebaran.

Selanjutnya untuk mencari korelasi antara variabel dependent dan variabel independent digunakan analisis regresi, serta mencari sumbangan efektif dari kedua variabel independent. Sedangkan untuk menguji hipotesis ke-4 (menguji perbedaan) maka uji prasyarat yang dibutuhkan adalah uji homogenitas. Data yang diperoleh dianalisis dengan menggunakan bantuan komputer SPSS 11 for Windows.

\section{Hasil Penelitian}

Dari hasil pengumpulan data diperoleh data-data tentang kategori subjek penelitian. Ada 5 (lima) macam kategori subjek yang digunakan dalam penelitian ini yaitu "sangat rendah" ( $\mathrm{X} \leq \mathrm{m}+-1.5 \mathrm{SD})$; "rendah" $(\mathrm{m}+-1.5 \mathrm{SD}<\mathrm{X} \leq \mathrm{m}+$ $0.5 \mathrm{SD})$; "sedang" ( $\mathrm{m}+-0.5 \mathrm{SD}<\mathrm{X} \leq \mathrm{m}+0.5 \mathrm{SD})$; "tinggi" $(\mathrm{m}+0.5 \mathrm{SD}<\mathrm{X} \leq$ $\mathrm{m}+1.5 \mathrm{SD})$; dan "sangat tinggi" $(\mathrm{m}+1.5 \mathrm{SD}<\mathrm{X})$. Kategori subjek di atas digunakan untuk mengelompokkan skor dari ketiga variabel dalam penelitian ini (Azwar, 2009: 23).

\section{Skala Kemandirian}

Kategorisasi subjek pada skala kemandirian disajikan pada tabel di bawah ini.

\begin{tabular}{|c|l|c|l|c|}
\hline No & \multicolumn{1}{|c|}{ Skor } & Jumlah & \multicolumn{1}{|c|}{ Kategori } & Persentase \\
\hline 1 & $\mathrm{X} \leq 8.499$ & 0 & Sangat Rndah & $0 \%$ \\
\hline 2 & $8.499<\mathrm{X} \leq 14.166$ & 0 & Rendah & $0 \%$ \\
\hline 3 & $14.166<\mathrm{X} \leq 19.834$ & 10 & Sedang & $14.706 \%$ \\
\hline
\end{tabular}




\begin{tabular}{|l|l|l|l|l|}
\hline 4 & $19.834<\mathrm{X} \leq 25.501$ & 30 & Tinggi & $44.118 \%$ \\
\hline 5 & $25.501<\mathrm{X}$ & 28 & Sangat tinggi & $41.176 \%$ \\
\hline
\end{tabular}

2. Skala Dukungan Sosial

Kategorisasi subjek pada skala dukungan sosial disajikan pada tabel di bawah ini.

\begin{tabular}{|c|l|c|l|c|}
\hline No & \multicolumn{1}{|c|}{ Skor } & Jumlah & \multicolumn{1}{|c|}{ Kategori } & Persentase \\
\hline 1 & $\mathrm{X} \leq 8.499$ & 0 & Sangat Rndah & $0 \%$ \\
\hline 2 & $8.499<\mathrm{X} \leq 14.166$ & 2 & Rendah & $2.941 \%$ \\
\hline 3 & $14.166<\mathrm{X} \leq 19.834$ & 4 & Sedang & $5.882 \%$ \\
\hline 4 & $19.834<\mathrm{X} \leq 25.501$ & 22 & Tinggi & $32.353 \%$ \\
\hline 5 & $25.501<\mathrm{X}$ & 40 & Sangat tinggi & $58.824 \%$ \\
\hline
\end{tabular}

3. Skala Optimisme

Kategorisasi subjek pada skala optimisme disajikan pada tabel di bawah ini.

\begin{tabular}{|c|l|c|l|c|}
\hline No & \multicolumn{1}{|c|}{ Skor } & Jumlah & \multicolumn{1}{|c|}{ Kategori } & Persentase \\
\hline 1 & $\mathrm{X} \leq 7.749$ & 0 & Sangat Rndah & $0 \%$ \\
\hline 2 & $7.749<\mathrm{X} \leq 12.916$ & 1 & Rendah & $1.471 \%$ \\
\hline 3 & $12.916<\mathrm{X} \leq 18.084$ & 8 & Sedang & $11.765 \%$ \\
\hline 4 & $18.084<\mathrm{X} \leq 23.251$ & 26 & Tinggi & $38.235 \%$ \\
\hline 5 & $23.251<\mathrm{X}$ & 33 & Sangat tinggi & $48.529 \%$ \\
\hline
\end{tabular}

Untuk melakukan uji hipotesis perlu dilakukan dahulu uji prasyarat terhadap data penelitian. Uji prasyarat yang dilakukan adalah uji normalitas, uji linearitas dan uji homogenitas.

Setelah uji prasyarat dilakukan dan terbukti bahwa data penelitian memenuhi syarat normalitas sebaran, linearitas sebaran, dan homogenitas varians maka penghitungan dilanjutkan dengan menggunakan teknik analisis regresi untuk menguji hipotesis 1, 2 dan 3 yang diajukan, sedangkan untuk hipotesis 4 menggunakan $t$-test. 
a. Hipotesis 1

Hipotesis 1 berbunyi "ada hubungan antara dukungan sosial dan optimisme dengan kemandirian lansia“. Berdasarkan hasil analisis regresi diperoleh koefisien korelasi $\mathrm{R}$ sebesar 0.347 , nilai $\mathrm{F}$ sebesar 4.463 dengan signifikansi $0.015(\mathrm{p}<0.05)$. Artinya ada hubungan positif yang signifikan antara dukungan sosial dan optimisme dengan kemandirian lansia. Berdasarkan hasil analisis tersebut maka hipotesis 1 dinyatakan DITERIMA, di mana semakin tinggi dukungan sosial dan optimisme maka akan semakin tinggi pula tingkat kemandirian lansia, dan juga sebaliknya.

Koefisien determinasi sebesar 0.121 memperlihatkan bahwa dukungan sosial dan optimisme memberikan sumbangan sebesar $12.1 \%$, yang berarti ada pengaruh variabel lain sebesar $(100 \%-12.1 \%=87.9 \%)$ terhadap kemandirian.

b. Hipotesis 2

Hipotesis 2 berbunyi "ada hubungan antara dukungan sosial dengan kemandirian lansia“. Berdasarkan hasil analisis regresi diperoleh $\mathrm{R}$ sebesar 0.310 dengan signifikasi $0.005(\mathrm{p}<0.01)$. Artinya ada hubungan positif yang sangat signifikan antara dukungan sosial dengan kemandirian lansia. Berdasarkan hasil analisis tersebut maka hipotesis 2 dinyatakan DITERIMA, di mana semakin tinggi dukungan sosial maka akan semakin tinggi pula tingkat kemandirian lansia, dan juga sebaliknya. 
Koefisien determinasi sebesar 0.0961 memperlihatkan bahwa dukungan sosial memberikan sumbangan sebesar 9.61 persen, yang berarti ada pengaruh variabel lain sebesar 90.39 persen terhadap kemandirian.

c. Hipotesis 3

Hipotesis 3 berbunyi "ada hubungan antara optimisme dengan kemandirian lansia“. Berdasarkan hasil analisis regresi diperoleh $\mathrm{R}$ sebesar 0.244 dengan signifikansi sebesar $0.022(\mathrm{p}<0.05)$. Artinya ada hubungan yang signifikan antara optimisme dengan kemandirian lansia. Berdasarkan hasil analisis tersebut maka hipotesis 3 dinyatakan DITERIMA, di mana semakin tinggi optimisme maka akan semakin tinggi pula tingkat kemandirian lansia, dan juga sebaliknya.

Koefisien determinasi sebesar 0.0595 memperlihatkan bahwa optimisme memberikan sumbangan sebesar 5.95 persen, yang berarti ada pengaruh variabel lain sebesar 94.05 persen terhadap kemandirian.

\section{d. Hipotesis 4}

Hipotesis 4 berbunyi "ada perbedaan kemandirian antara laki-laki dan perempuan lansia “. Berdasarkan hasil $t$ - test pada analisis tambahan diperoleh nilai t sebesar 0.240 dengan signifikansi $0.66(\mathrm{p}>0.05)$. Artinya tidak ada perbedaan kemandirian antara lansia laki-laki dengan lansia perempuan. Berdasarkan hasil analisis tersebut maka hipotesis 4 dinyatakan DITOLAK, dimana tidak ada perbedaan kemandirian antara lansia lakilaki dengan lansia perempuan. Meskipun apabila dilihat berdasarkan matrik statistik nampak adanya perbedaan skor antara mean kemandirian lakilaki $=24.31 ; \mathrm{SD}=$ 
4.471; sedangkan kemandirian perempuan diperoleh mean $=24.06 ; \mathrm{SD}=$

4.242. Perbedaan skor tersebut nampaknya kurang signifikan (terlau kecil) sehingga dapat dikatakan bahwa kedua kelompok tersebut tidak berbeda.

Berdasarkan hasil analisis regresi maupun t-test dapat disimpulkan bahwa hipotesa 1,2,3 diterima sedangkan hipotesa 4 ditolak dalam penelitian ini.

\section{Pembahasan}

Hipotesis 1 menyatakan bahwa ada secara bersama-sama dukungan sosial dan optimisme memiliki peranan terhadap kemandirian pada lansia. Penelitian membuktikan bahwa semakin tinggi dukungan sosial dan optimisme maka akan semakin meningkatkan pula kemandirian pada lansia. Hasil ini ditunjukkan dengan perolehan nilai koefisien korelasi (R) sebesar 0.347 , dengan signifikansi 0.015 ( $\mathrm{p}<0.05)$. Peranan variabel dukungan sosial dan optimisme terhadap kemandirian tersebut dapat diperjelas dengan teori yang dikemukakan oleh Johnson dan Johnson (2001: 98), yang menjelaskan bahwa dukungan sosial sebagai pertukaran sumber-sumber dimaksudkan dapat untuk saling mempertinggi kesejahteraan dan keberadaan orang lain, yaitu dengan cara saling memberikan bantuan, dorongan, penerimaan dan perhatian apabila ada orang lain yang mengalami kesulitan.

Kesejahteraan seseorang mampu dicapai apabila orang tersebut mampu memenuhi kebutuhan hidupnya sendiri dan tidak menggantungkan hidupnya pada orang lain. Itulah yang mendasari lansia untuk tetap melakukan berbagai aktivitas yang bisa menghasilkan finansial, minimal untuk mencukupi kebutuhan hidupnya sendiri. Ada kecenderungan lansia untuk tinggal berdua saja dengan suami/isteri 
karena tidak mau merepotkan anak atau keluarganya. Untuk mampu menumbuhkan sikap mandiri tentunya memang ada keinginan atau dorongan dari dalam diri lansia bahwa tidak ingin merepotkan orang lain. Keinginan untuk tetap berusaha atau menghasilkan sesuatu yang bermanfaat sejalan dengan pendapat Ascierer dan Carves (dalam Mathews,dkk, 2009: 38) individu yang optimis adalah individu yang mengharapkan hasil positifnya. Jadi yang dipikirkan adalah hasil dari usahanya tersebut akan bermanfaat. Lansia dalam penelitian ini hampir semuanya masih mampu melakukan aktivitas bahkan masih ada yang bekerja walaupun tidak tetap.

Hal tersebut sejalan dengan paradigma continuity theory yang menjelaskan bahwa lansia merasa berhasil dalam masa tuanya ditunjukkan dengan kemampuannya untuk tetap mampu menjaga kebiasaan-kebiasaannya, hubungannya dengan orang lain maupun aktivitasnya. Likert (1991: 61) menjelaskan bahwa salah satu aspek kemandirian yaitu perasaan berharga sangat dipengaruhi oleh respon yang diperoleh dari individu -individu yang dekat dalam rangka mendapatkan penerimaan dan hubungan yang baik dari lingkungan. Shapiro (2008: 56) menerangkan bahwa seseorang yang mempunyai pikiran yang optimis bisa menjadi semacam imunisasi psikologis yang mampu menangkal segudang masalah dalam kehidupan sehari-hari.

Hipotesis kedua yang menerangkan bahwa ada hubungan antara dukungan sosial dengan kemandirian memberikan kontribusi sumbangan sebesar $9.61 \%$ terhadap kemandirian pada lansia. Dukungan sosial mempunyai peran yang cukup penting, dimana melalui dukungan sosial yang meliputi dukungan emosi, 
penghargaan, materi, informasi maupun umpan balik secara langsung maupun tidak langsung akan mempengaruhi: produktivitas hidup individu (dimana individu akan memiliki motivasi yang meningkat, keberhasilan dalam memecahkan masalah, tekun menyelesaikan dalam suatu pekerjaan saat berada pada kondisi yang menekan, beraspirasi pada karir sehingga dukungan sosial dapat mengurangi stres kerja, stres akibat kehilangan dan kondisi stres yang lain); kesejahteraan psikologis (psychological well being) menjelaskan bahwa dukungan sosial akan berpengaruh pada kesejahteraan psikologis ; meningkatkan identitas diri, dan self esteem individu. (Ascierer dan Carves; dalam Matthews, dkk, 2009: 99).

Hipotesis ketiga yang menerangkan bahwa "ada hubungan antara optimsme dengan kemandirian" memberikan kontribusi R sebesar 0.244 dengan signifikansi sebesar $0.022(\mathrm{p}<0.05)$. Artinya ada hubungan yang signifikan antara optimisme dengan kemandirian lansia. Sumbangan optimisme sebesar 5.95 $\%$ terhadap kemandirian pada lansia, nampaknya sejalan dengan penelitian yang dilakukan oleh Seligman (2005: 56) terhadap orang dewasa diperoleh hasil bahwa individu yang optimis jarang menderita depresi, lebih sukses di sekolah atau di pekerjaan, apalagi diperoleh hasil yang mengejutkan dimana individu yang optimis tersebut memiliki tubuh yang lebih sehat daripada individu yang pesimis.

Drive theory atau teori dorongan yang dikemukakan oleh McCandless (1980: 70) menyatakan bahwa perkembangan tingkah laku seseorang dibentuk oleh adanya dorongan dari dalam diri individu. Salah satu fungsi dorongan tersebut adalah sebagai energi bagi individu untuk bertingkah laku. Makin 
meningkat umur seseorang akan makin meningkat dorongan seseorang untuk melakukan sesuatu. Penelitian yang dilakukan oleh Krueger dan Heckhausen (2003: 34) dengan meminta pendapat kepada orang-orang dewasa muda; paruh baya; dan lanjut usia tentang 100 gambaran sifat dengan memandang masa sepuluh tahun dari kehidupan masa dewasa. Hasil yang diperoleh orang-orang lansia lebih suka memilih gambaran sifat-sifat yang optimis mengenai perkembangan akhir kehidupannya dibandingkan dengan rekan-rekannya yang lebih muda.

Pengujian terhadap hipotesis ke-4 yang menyatakan "ada perbedaan kemandirian antara lansia laki-laki dengan lansia perempuan" tidak terbukti. Hal tersebut dapat dilihat dengan besarnya koefisien perbedaan $t$ sebesar 0.240 dengan signifikansi $0.66(\mathrm{p}>0.05)$. Meskipun banyak tokoh yang menyatakan bahwa laki-laki diharapkan untuk lebih aktif dalam mencapai kemandirian, lebih memperhatikan hal-hal yang berkaitan dengan harga diri, bertanggung jawab dan mampu mengontrol emosinya. Wanita tidak terlalu dituntut untuk mencapai halhal tersebut. Wanita lebih dituntut untuk pasif, toleran, dan lemah lembut (Conger, 1987: 77). Pendapat serupa juga dikemukakan oleh Kimmel (dalam Masrun, dkk, 1996: 55) yang menyatakan bahwa wanita mempunyai ciri-ciri mudah dipengaruhi, sangat submissive, sangat pasif, tidak menyukai petualangan, merasa kesulitan dalam memutuskan sesuatu, kurang percaya diri, tidak ambisius dan sangat tergantung. Sedangkan laki-laki dituntut untuk tidak mudah dipengaruhi, dominan, sangat aktif, dapat memutuskan sesuatu secara mudah, suka berpetualang, sangat percaya diri, ambisius dan tidak tergantung. Dengan melihat 
tuntutan-tuntutan yang berbeda pada laki-laki dan wanita, nampaknya laki-laki menjadi lebih mandiri dibandingkan dengan wanita karena laki-laki akan berusaha memenuhi tuntutan-tuntutan masyarakat tersebut.

\section{Keimpulan dan Saran}

Berdasarkan hasil penelitian yang telah dilakukan dapat ditarik beberapa kesimpulan sebagai berikut.

1. Ada hubungan yang signifikan antara dukungan sosial dan optimisme dengan kemandirian lansia.

2. Ada hubungan yang sangat signifikan antara dukungan sosial dengan kemandirian lansia.

3. Ada hubungan yang signifikan antara optimisme dengan kemandirian lansia.

4. Tidak ada perbedaan kemandirian antara lansia laki-laki dan lansia perempuan.

5. Tingkat dukungan sosial subjek secara umum termasuk dalam kategori sangat tinggi, tingkat optimisme termasuk sangat tinggi, dan tingkat kemandirian secara umum termasuk tinggi.

Berdasarkan simpulan tersebut peneliti mengajukan beberapa saran sebagai berikut.

1. Optimisme diharapkan masih dimiliki lansia meski telah terjadi penurunan pada segala aspek kehidupan lansia.

2. Lingkungan diharapkan selalu memberikan dukungan terhadap keberadaan lansia, agar lansia mampu menjalankan aktivitas kehidupannya secara mandiri. 
3. Peneliti selanjutnya diharapkan mau melakukan penelitian terhadap variabelvariabel lain yang terkait dengan kemandirian lansia misalnya harga diri, status sosial ekonomi, jenis pekerjaan, maupun tingkat pendidikan. Menindaklanjuti proses pengambilan data sebaiknya dilakukan dengan teknik wawancara, mengingat subjek lansia lebih suka apabila diminta untuk bercerita daripada melakukan aktivitas yang berkaitan dengan menulis, membaca atau berfikir.

\section{Daftar Pustaka}

Arikunto, Suharsimi. 2002. Prosedur Penelitian: Suatu Pendekatan Praktek. Jakarta: Penerbit Rineka Cipta.

Azwar, S. 2008. Tes Prestasi. Yogyakarta: Pustaka Pelajar Offset. . 2009. Penyusunan Skala Psikologis. Yogyakarta: Pustaka Pelajar Offset.

Cohen, S., dan Syme, L. 2005. Social Support and Health. Florida: Academic Press.

Conger, J.J. 1987. Adolescence and Youth. Second Edition. New York: Harper and Row. Publisher, Inc.

Darmojo, B. 2007. Populasi Lanjut Usia dan Kebijakan Sosial bagi Lansia di Indonesia. Buletin Gerontologi dan Geriatri. 15-16.

Gottlieb, B.H. 2003. Social Support Strategies. Beverly Hill, C A: Sage.

Haditono, S. R. 1999. Kebutuhan dan Citra Diri Orang Lanjut Usia. Laporan Penelitian. (Tidak Diterbitkan). Yogyakarta: Fakultas Psikologi Universitas Gadjah Mada.

House, J. dan Kahn, R.L. 1995. Measures and Concept of Social Support. London: Academic Press, Inc.

Hurlock, E.B. 2003. Psikologi Perkembangan: Suatu Pendekatan Sepanjang Rentang Kehidupan (Terjemahan: Istiwidayanti dan Soedjarwo). Jakarta: Penerbit Erlangga. 
Ibrahim, Alhamd, M. 2007. Menumbuhkan Optimisme Motivasi dan Hambatan. Jakarta: Daarul Haq.

Johnson, D.W dan Johnson, F.P. 2001. Joining Together: Group Theory and Group Skill ( fourth ed.). New York: Prentice Hall International.

Likert, R. 1991. New Patterns of Management. New York: McGraw-Hill Book Company, Inc.

Matthews, K.A., Flory, J.D., Owens, J.F., Gump, B.B. \& Raikkonen, K. 2009. Effect of Optimism, Pesimism, and Trait Anxiety on Ambulatory Blood Pressure and Mood during Everyday Life. Journal of Personality and Social Psychology. 76, 104-113.

McGinnis, A. L. 2005. Kekuatan Optimisme (Terjemahan: Anton Adiwiyoto) Jakarta : Mitra Utama.

Santrock, J.W. 2007. Life Span Development : Perkembangan Masa Hidup. (Terjemahan Achmad Chusairi dan Juda Damanik). Jakarta: Erlangga.

Sarason, I. G., Levine, H. M. Basham, R. B., dan Sarason, B. R. 193. Assessing Social Support : The Social Support Questionare. Journal of Personality and Social Psychology. Vol. 44. 127-139.

Seligman, M.E.P.2001. Learned Optimism. New York: Alfred A Knopf Publishers.

.2005. Child Optimism. New York: Alfred A Knopf Publishers.

Smart, M.S., Smart, R.C. dan Smart, L.S. 2008. Adolescent Development and Realtionships. New York : Mc Millan Publishing Co. Inc.

Smet, B. 2004. Psikologi Kesehatan. Jakarta : Grasindo.

Vaughan, S. 2005. Sudahkah Anda Positive Thingking? Kosmopolitan. edisi: 26 Juni 